\title{
Kernos
}

Revue internationale et pluridisciplinaire de religion grecque antique

8| 1995

Varia

\section{Body and Soul in Plato's Anthropology}

\section{Conrado Eggers Lan}

\section{(2) OpenEdition \\ Journals}

\section{Electronic version}

URL: https://journals.openedition.org/kernos/592

DOI: 10.4000/kernos.592

ISSN: 2034-7871

\section{Publisher}

Centre international d'étude de la religion grecque antique

\section{Printed version}

Date of publication: 1 January 1995

Number of pages: 107-112

ISSN: 0776-3824

\section{Electronic reference}

Conrado Eggers Lan, "Body and Soul in Plato's Anthropology", Kernos [Online], 8 | 1995, Online since 11 April 2011, connection on 21 September 2021. URL: http://journals.openedition.org/kernos/592 ; DOI: https://doi.org/10.4000/kernos.592 


\section{Body and Soul in Plato's Anthropology"}

Perhaps Plato is the first philosopher who settles the dualism body-soul in the history of Greek thought ${ }^{1}$. Of course, at least since Herodotus (i.e. ca 450 B.C.) we hear about the soul's immortality after the body's wasting away (II, 123). And the Potidaea's inscription ("aither received souls; earth, bodies", if the reconstruction of the end of the line is right) shows that, by the year 432 B.C., at least some people thought that the fate of the $\psi v x \eta$ could be other than the one of the $\sigma \hat{\omega} \mu \alpha$, both of these being thereby two different "components" of the man alive. But you can never know, in these cases, what is exactly meant by $\psi v \chi \grave{\eta}$ and $\sigma \hat{\omega} \mu \alpha$. The text of Potidaea's inscription is similar to the one of

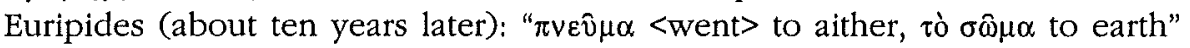
(Suppl., 533-534). And $\pi v \varepsilon v \hat{\mu} \alpha$ means here, as $\psi v x \grave{\eta}$ often does, "breath" or "breath of live". It is to be reminded that still Diogenes of Apollonia claims that

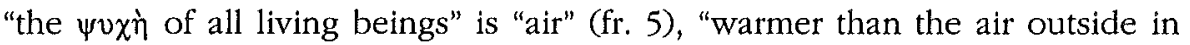
which we are, but much colder than that near the sun"; and a little after (according to the long Simplicius' quotation) qualifies this "eternal air" as $\sigma \hat{\omega} \mu \alpha$ (fr. 7) ${ }^{2}$.

Now we read in Plato's Gorgias (524b2): "Death is not anything but, in my opinion, the loosening $\left(\delta \alpha^{\prime} \lambda v \sigma 1 \zeta\right)$ of two things one from another, soul and body". Clearer still — because the idea is now developed- we find in Pbaedo (64c4-8): "And do we think of it ( $s c$. death) as anything but the departure ( $\alpha \dot{\pi} \alpha \lambda \lambda \alpha \gamma \eta$ ) of soul from body, and of being dead as the separated being

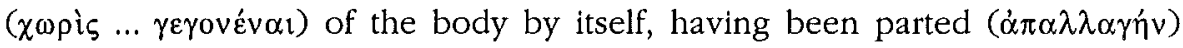

- This paper was presented for the first time to a meeting organised by the Fundación Ortega y Gasset on "The subject of Man", in Buenos Aires, september 1993. Here I make only a couple of additions: two foot-notes ( 2 and 7 ) where I take in account two worthwile objections cordially made to me in that occasion by Miles Burnyeat.

1 I take as proved by B. SNELL (Die Entdeckung des Geistes, Hamburg, 1955 ${ }^{3}$, chap. I esp. p. 2142) that before the 5th cent. B.C. the Greeks had not a conception of "body" and "soul" such as the one they had from that moment. Nonetheless, I don't agree with him on that the evolution of these notions consists in the discovery of such a dualism (cf. my essay El concepto de alma en Homero, Facultad de Filosofía y Letras, $1987^{3}$ [1967], p. 25). I rather think that this dualism arose once upon a time, in philosophical analysis; and that it fulfilled a very useful function during centuries. I only wonder if it remains useful to-day, and, above all, if it corresponds strictly to human reality, even at earlier Greek times,

2 As another sample of Presocratic use of $\sigma \hat{\omega} \mu \alpha, M$. Burnyeat (see supra, n. *) reminded me Melissus' fr. 9: "Now, if it is, it must be one; and being one, it must have no $\sigma \hat{\omega} \mu \alpha$ ". But I don't know, once more, what $\sigma \hat{\omega} \mu \alpha$ means here, especially when it is not opposed to $\psi v \chi \dot{\eta}$, not even as the Potidaea's case. 


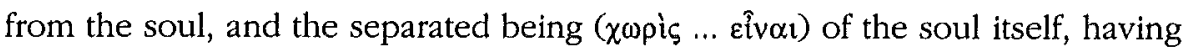
been parted ('่ $\pi \alpha \lambda \lambda \alpha \gamma \varepsilon \hat{\imath} \sigma \alpha v)$ from the body?". Hackforth (Plato's Phaedo, p. 44 n. 1) claims that such a "definition of death" doubtless represents the normal contemporary view (my italics), but he brings a testimony about Chrysippus and other later texts as examples ${ }^{3}$.

In fact, by no means do we know that such a view was "contemporary" to Plato, though we can imagine that some similar thought lay behind the Potidaea's and Euripides' sentences. However, it all depends on the meaning of both notions, body and soul, or of both Greek words, $\sigma \hat{\omega} \mu \alpha$ and $\psi v \chi x^{\prime}$. (Because finally we can go back even to Homer, who already talks about $\sigma \hat{\omega} \mu \alpha$ and $\psi v \chi \eta^{\prime}$ at death -and only at death, $\psi v x \dot{\eta}$ being the last breath or departed spirit and $\sigma \hat{\omega} \mu \alpha$ the remaining corpse.)

Of course, it is very difficult to draw a sharp line between the time when the bodiless nature of soul is asserted first, and the previous time; but in fact we have no certain evidence thereof before Plato's Phaedo. To be sure, Plato does not say explicity in Pbaedo that soul is incorporeal: he uses once the word $\dot{\alpha} \sigma \omega \mu_{\alpha} \tau_{0 \varsigma}$ (85e5: the first use of this word, insofar as I know) referring to the attunement of the lyre, while the lyre itself is a body; but it is a comparison made by Simmias with Socrates' precedent argument about the different nature of body and soul (78b-80d). And I do not know earlier texts pointing to any kind of difference in nature between them.

Now, what short of dualism is this which is posed by Plato? Is it a cosmic one or an anthropological one, or both?

We know, indeed, that Plato poses a cosmic dualism (for the first time, also

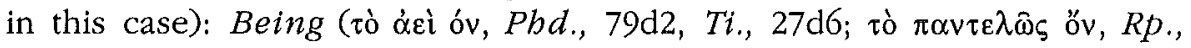
477a2; ovoía, Rp., 534a2-3, Sph., 248a7, a11, Pblb., $54 a 5$ ff., etc.) and Becoming (often without this specific name, refering only to "visible things";

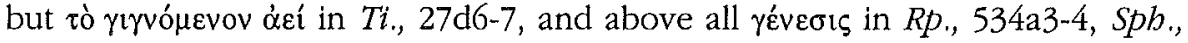
248a7, a10, a12, Pblb., $54 a 5$ ff., etc.).

However, we can see, on the one hand, that this ontological dualism, which is so sharply drawn in Pbaedo, becomes a source of several difficulties for Plato (cf. Parmenides, 130b-134e), who tries to build a bridge between the two kinds, such as the one which the notion of World-Soul offers in Pbilebus, Timaeus and Laws.

On the other hand, in the passage $P b d ., 79 a-80 a$ referred to above, Plato does not put the anthropological dualism body-soul in a way so clear and sharp as he does in the case of the cosmic one: soul is akin "to what is divine and deathless", while body is akin "to what is buman and mortal" (80b1, b3-4).

3 HACKFORTH quotes, besides this testimony ( $S V F$, II, 790, after Nemesius Emesenus), another allegedly belonging to Epicureans apud Lucrecio (III, 838-839), and a passage (471b) of the peripathetic treatise De resplratione referring to Democritus (D.-K. 68 A 106), which does not seem appropriate to the point. In a wiser way, DODDS (Plato's Gorglas, p. 379) quotes only Hackforth's references to Stoics and Epicureans, and says: "the definition <of death> was accepted both by Stoics... and by Epicureans" (my italics). 
To be sure, the division between the invisible-divine-deathless and the visible-human-mortal is sharp and clear: Plato has begun the passage postulating that "there are two kinds of thing (or "existents", as Bluck translates ob $v \alpha$ ), the visible and the invisible" (79a6-7), and developing their differences: one kind is, besides visible, never constant, not intelligible, human, etc., while the invisible kind is always constant, intelligible, divine, etc.

Now, Plato says, "we ourselves (i.e. men) are partly body, partly soul" (79b1-2, Hackforth's translation). At this point we would say that soul belongs to the invisible kind of thing, since it is just invisible, and that body, in the same way, belongs to the visible kind. Plato, however, does not assert that, but that

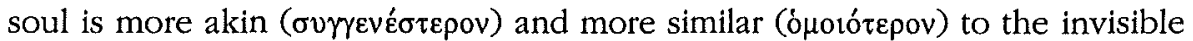
than body is, and body is more akin and more similar to the visible than soul is (79b4-80b5).

But what do the qualifications "akin" and "similar" mean in such a context? In fact, it is noteworthy that $\sigma \hat{\omega} \mu \alpha$, in Phaedo, is never referred to other bodies than the human one, even when Plato criticizes the Presocratic's views on nature, 96a ff. (the sole exception would be Simmias' assertion on the lyre and cords as bodies, but it is clear that it is only a comparison, later rejected by Socrates). It happens similarly at the other middle dialogues, although the dualism body and soul is sometimes referred to other living beings, especially to gods or stars, explicitly at Pbaedrus (245e ff.; cf. Rep., VII, 530b3).

It is firstly at Sopbist, where Plato - perhaps under the influence of the "earth-borns" described at $246 \mathrm{a} \mathrm{ff}$., who reduce everything to bodies- talks about bodies other than those of living beings: just "lifeless bodies", "̋ $\psi v \chi \alpha$ $\sigma \omega \mu \alpha \tau \alpha(227 \mathrm{a} 3, \mathrm{~b} 7,265 \mathrm{c} 3)$. In the Politicus we find the term "body" in a sense close to the aristotelian " $\lambda \eta$ (Skemp translates it "stuff"; see his foot-note at $258 \mathrm{e} 2$ and $288 \mathrm{~d} 2$ ), in the scope of craftsmanship.

Now in Politicus (269d6) it is also referred to the bodily nature of the universe, for the first time ${ }^{4}$. And this view is developed at Philebus, Timaeus and Laws X. In Pbll., 30a6 we hear that "the body of the universe is ensouled"

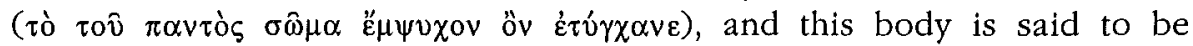
constituted by fire, water, air and earth (29a10), i.e. the so-called elements. And this World-Soul rules, like the human soul, through its intellect, and in its case it rules the universe (and it is said "regal", like in Phaedrus, and in the same way it is called again "Zeus", $30 \mathrm{~d} 1$ ).

And in Timaeus this constitution of the universe out of fire, water, air and earth is carried on to its ultimate elements, which are triangles. Thereby Plato

4 Indeed W. THEILER (Zur Gescbicbte der teleologischen Naturbetracbtung bis auf Aristoteles, Zürich-Leipzig, 1925, p. $14 \mathrm{ff}$.) goes back to Diogenes of Apollonia, through Xenophon's Memorabilia, I, 4, 17, for the conception of a world-body and of a world-soul, paralleling with Phlb., 28-30. But it is by no means sure that Xenophon's passage has been previous to Plato's Philebus. Moreover, the fr. 5 and 7 of Diogenes show, as we have seen, no clear dualism between body and soul. To be sure, Theiler's main point is the teleological view, and we can agree with him that it is already present in Diogenes. 
poses a mathematical construction of matter - something which has been much discussed, whether it is a genial anticipation of modern physical theories, or merely a fantasy. Concerning our present research, we must say that it is the first time that fire, water, air and earth are said to be "bodies" (53c4), and, insofar as they constitute the world's body, it is spoken of as what to-day we call "universe's matter" and naming it "body". It is noteworthy, besides, that it is also the first time - at least insofar as we know - that we can see the word "body" applied to the regular solids: "All body (or "every kind of body", or

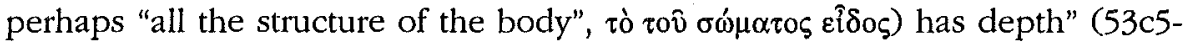
6). It is an uncommon use of the word, since Euclides himself mentions "solids" and "solid figures" (XIII def. 1, 9, 10) $)^{5}$. Perhaps this new platonic use is due to the effort to abstract, as much as possible, the notion of "body" (thus the word Ei $\left.\delta \delta_{5}\right)$, in order to go into the ultimate "elements" of the world-body.

But we must notice that this ensouled body which the world consists of is "a perceptible (or "sensible", $\alpha i \sigma \theta \eta \tau$ 'ó $)$ god" (92c7), that is, a being who is intermediate between the invisible realm and the visible one (or, in the terms of 35a1-6, between the "indivisible being" and the "divisible being") 6 .

This mixed composition of the world thus becomes a corroboration of the particular way of man's being, whose soul had been said "more akin" to the Ideas, while his body was "more similar" to the other visible things which surround us.

Now, since Plato defines death in Pbaedo, as "the departure of soul from body" and caracterizes "the pursuit of philosophy" as "training for dying and being dead" (64a5-6), we would expect that Plato depicted body only as an obstacle for man. However, it is not so: without his body, Plato says, Socrates would not be able to do what he thinks is best (99a5-7). Even it is only from the bodily perception that we can know the things themselves (75a5-7).

In fact, Plato cannot conceive buman soul (nor any soul) without body. Neither can the gods' souls dispense with body (Pbdr., 246d1, Ti., $40 \mathrm{ff}$, Laws, $\mathrm{X}, 889 \mathrm{~b} 5-7)^{7}$. Not even the highest soul, the World-Soul, can.

5 E. SACHS (Dle fünf platonischen Körper, Berlin, 1917, p. 2) takes as granted that the "Philolaus" fragment 12 belongs to an ancient tradition; but I think that to-day its inauthenticity is proved (cf. W. BURKERT, Weisheit und Wissenschaft, Nürnberg, 1962, p. 255 and n. 206 [= Lore and Science, Cambridge Mass., 1972, p. 276 and n. 183). Xenokrates, fr. 53 Heinze, talks about "five figures and bodies", and Ps.-Plato's Eplnomis, $981 \mathrm{~b} 3$ about "solid bodies" (cf. L. TARÁN, Academica, Philadelphia, 1975, p. 39, n. 176, and p. 263). Perhaps in the Academy the term "body" was used by some mathematicians in the platonic sense, and thence we can read in Aristotle its definition as "that which has three dimensions" (Topica, 142b24; see many other examples in BONITZ, ad $\sigma \hat{\omega} \mu \alpha)$. Anyway, all the testimonies about the geometrical use of "body" are posterior to Plato.

6 Cf. H. CHERniss, Aristotle's Criticism of Plato and the Academy, New York, $1962^{2}$, p. 407-411 and p. $606 \mathrm{ff}$.

7 Regarding the Phaedrus' passage, M. Burnyeat (see note ") objected to me that there Plato exposes a popular view which he does not share. I agree that it is a popular conception, but I think that the Timaeus' and Law' passages which I quote show that Plato shares it. And besides, the view 
To be sure, Plato talks more than once about human soul without its body: e.g. Gorgias, 523c-e, where souls, after death, go on to be judged "naked", "stripped" of their body; Phd., 76c-e, where it is said that our souls knew the Ideas before birth, when they lived in Hades, deprived of bodies; and other passages from Plato's eschatological myths.

But all this kind of tales belongs to myths (even the quoted passage of Pbaedo, as I tried to show elsewhere ${ }^{8}$ ). It is not even consistent with what is said in other mythical passages, like that of the final myth of Pbaedo, where only those few men "who have purified themselves enough through philosophy live without body all time to come" (114c2-4).

Above all, if we take literally Phaedo's talking about the knowledge of Ideas in Hades (talking which is depicted as a $\mu v 0 \mathrm{o} \lambda \mathrm{o} \gamma \varepsilon \hat{\mathrm{i}} \mathrm{v}, 61 \mathrm{e} 2$ and 70b6), we should find a flagrant contradiction with Plato's interpretation of his own allegory of cave, where we can read that the released prisoner is the philosopher who attains the knowledge of the Ideas, but that, when he has looked upon them enough (ikavâs, 519d2), we must return to society: we must not allow him to spend all his life in contemplation, "believing that, while still living", he is "settled in the Islands of the Blest" (519c5-6).

But even in Pbaedo we are told that the true philosopher, "when taking reason as his guide and being always in the contemplation of what is true and divine and not conjectural, and nourishing itself on that; deems that it is in this way how he must live as long as he is alive, and that after death he arrives at what is akin to himself" (84a7-b2). In this passage Plato speaks clearly - like in Rep., V-VII - regarding the full (or nearly full) knowledge of Ideas during life, not after death.

In Sopbist, 249a4-10 Plato asserts that intellect (vovs) involves life, and that in its turn life implies soul and soul motion. We find the same implication intellect-soul in Pblb., 30c9, where we can read, instead of the sequence soulmotion, the previous bond soul-body (30a3, 6, b2). Similarly, but more strongly, in Timaeus, 30b3-5: "since it is impossible for the intellect to be present in anything apart from soul", the Demiurge "framed intellect within soul and soul within body".

Indeed, it is not said explicitly that it is impossible for the soul to exist apart from the body; but I think, pace the neoplatonistic interpretations, that the implication soul-body is so clear as the one intellect-soul, at least in late dialogues; and, as matter of fact, we find it also in middle dialogues.

Let us return now to the dualism body-soul in Pbaedo. The line which Plato draws there between the "two kinds of thing" is definite, but, as we have seen, the one drawn between body and soul is not so sharp. Why? Because Plato puts forward in Pbaedo a "two-dimensional" anthropology, if I am allowed to use a

that Plato does not conceive soul without body seems to be required by the soul's definition at $P b d r, 245 c-e$. I owe to Gabriela Carone for this last helpful observation.

8 El mito de la muerte de Sócrates en el Fedón, in Métbexis, 2 (1989), p. 19-28. 
Herbert Marcuse's term. The two kinds of thing mean two possible (opposite) goals of human behaviour, such as they are, for the divine Craftsman of Tim., $27 \mathrm{~d}-29 \mathrm{~b}$, two possible (opposite) patterns of making.

And man can choose between the two aims, because he shares in both, he is somebody (as philosopher, at least) who dwells in some intermediate realm (i.e. in the world-god). Body means first the obstacle (ह̋ $\mu \pi \circ \delta$ tov) which arises from human nature and that the philosopher must overcome, and in this sense it is like the cave from which the prisoners must release themselves. But body means besides the condition without which the philosopher cannot reach any degree of truth, the means through which the knowledge of Ideas becomes possible. Thence body is for man, at the same time, source both of slavery and freedom.

Conrado EGGERS LAN

Universidad de Buenos Aires - CONICET

Las Heras 1543

1714 ITUZaingo, Prov. Buenos Aires

Argentina 